Dicle Tıp Dergisi / Dicle Med J (2019) 46 (1) : 27 - 32

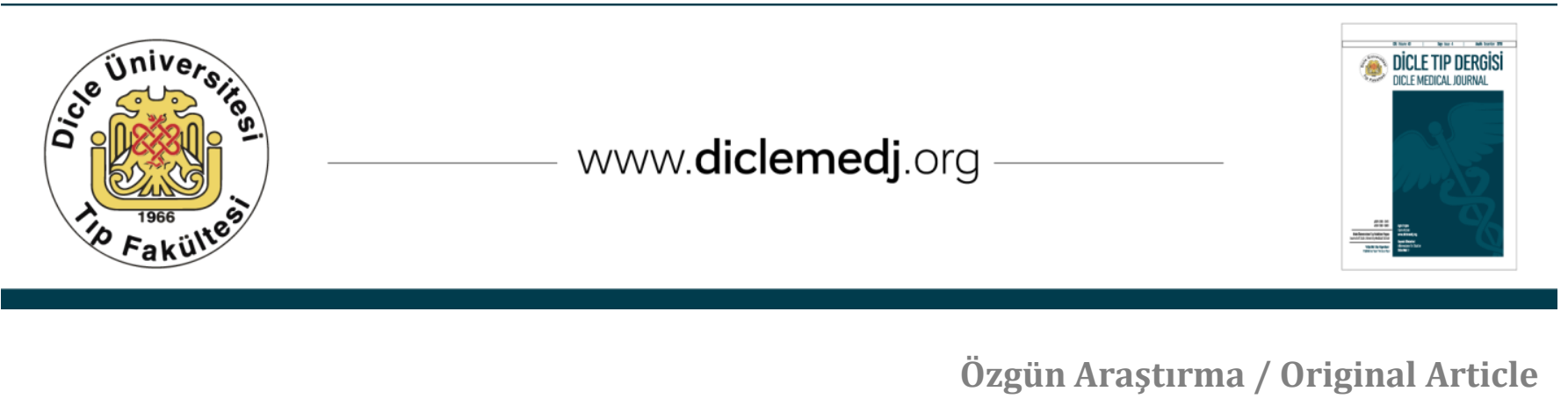

\title{
Pulmonary hamartoma: Retrospective analysis of 24 cases
}

\author{
Miktat Arif Haberal' ${ }^{1}$ Ozlem Sengoren Dikis ${ }^{2}$, Erkan Akar ${ }^{3}$
}

1 Dept. of Thoracic Surgery, Univ of Health Sciences Bursa Yuksek Ihtisas Training and Research Hospital, Bursa, Turkey ORCID: 0000-0002-1051-094X 2 Dept. of Pulmonary Diseases, Univ of Health Sciences Bursa Yuksek Ihtisas Training and Research Hospital, Bursa, Turkey 0RCID: 0000-0001-7005-3333 3 Dept. of Thoracic Surgery, Univ of Health Sciences Bursa Yuksek Ihtisas Training and Research Hospital, Bursa, Turkey ORCID: 0000-0002-9113-8237

Received: 11.10.2018; Revised: 05.01.2019; Accepted: 29.01.2019

\begin{abstract}
Objective: Lung hamartoma is the most frequently diagnosed benign lung tumor. The aim of this study was to investigate the clinical, radiological and pathological data of the patients with pulmonary hamartoma who underwent surgical treatment in our clinic.

Methods: Hospital records of 24 lung hamartoma patients given surgical treatment in our clinics between January 2005 and December 2017 were investigated retrospectively. In this study, these cases were evaluated with respect to age, gender, clinical, histopathological, and radiological features, and surgical methods.

Results: There were 24 patients with a mean age of 50.6 (23-66) years, consisting of 14 males and 10 females, who underwent surgical resection for pulmonary hamartoma was. While $17(42 \%)$ patients were asymptomatic, the rest complained of coughing, shortness of breath and repetitive lung infections. Hamartoma was localized in the right lung in 16 (67\%) of the cases; peripherally in 17 (71\%), and centrally in 7 (29\%). All patients underwent wedge resection, 17 cases by thoracoscopy and 7 cases by thoracotomy. The mean tumor diameter assessed macroscopically was 2.9 $\mathrm{cm}(1-4.5 \mathrm{~cm})$.

Conclusion: Pulmonary hamartomas frequently present as peripheral solitary nodules. Given its low morbidity and mortality, surgical resection is recommended for definitive diagnosis and treatment, the objective of the intervention being total excision of the lesion while protecting the lung parenchyma.
\end{abstract}

Keywords: surgical resection, hamartoma, pulmonary nodule.

DOI: $10.5798 /$ dicletip

Yazıșma Adresi / Correspondence: Ozlem Sengoren Dikis, Department of Pulmonary Diseases, Bursa Yuksek Ihtisas Training and Research Hospital, Bursa, Turkeye-mail: ozlemsengoren@hotmail.com 


\section{Akciğer hamartomu: 24 olgunun retrospektif analizi}

Öz

Amaç: Akciğer hamartomu akciğerin bening tümörleri içerisinde en sık karșılașılan tümörüdür. Bu çalışmanın amacı kliniğimizde cerrahi tedavi uygulanan akciğer hamartomlu olguların klinik, radyolojik ve patolojik özelliklerini incelemektir.

Yöntemler: Kliniğimizde Ocak 2005-Aralık 2017 tarihleri arasında cerrahi tedavi uygulanan akciğer hamartomlu 24 olgu retrospektif olarak incelendi. Çalışmamızda bu olgular; yaş, cinsiyet, klinik, histopatolojik ve radyolojik özellikleri, uygulanan cerrahi işlemler açısından değerlendirildi.

Bulgular: Akciğer hamartomu nedeni ile cerrahi rezeksiyon uygulanan 24 olgunun, 14 tanesi erkek, 10 tanesi kadın ve yaş ortalaması 50.6 (23-66) yıl idi. Erkek/kadın oranı 1.4 olarak tespit edildi. 24 olgunun 17'si (\%42) asemptomatik iken diğer hastalarda öksürük, nefes darlığı, göğüs ağrısı ve tekrarlayan akciğer enfeksiyonları mevcuttu. Hastaların 16'sında (\%67) tümör sağ akciğer yerleşimliydi. Lezyonların 17'si (\%71) periferik, 7'si (\%29) santral lokalizasyonluydu. Bütün olgulara wedge rezeksiyonu yapıldı. İşlem 17 olguya torakoskopik olarak yapılırken, 7 olguya torakotomi ile gerçekleștirildi. Makroskopik incelemede ortalama tümör çapı $2.9 \mathrm{~cm}(1-4.5)$ olarak tespit edildi.

Sonuç: Pulmoner hamartomlar sıklıkla periferik soliter pulmoner nodüller olarak ortaya çıkarlar. Kesin tanı ve tedavisinde düşük mortalite ve morbidite oranları olan cerrahi rezeksiyon önerilmektedir. Cerrahide amaç akciğer parankimini koruyarak lezyonun total eksize edilmesidir.

Anahtar kelime: cerrahi rezeksiyon, hamartom, pulmoner nodül.

\section{INTRODUCTION}

Hamartomas, presenting with a higher incidence in middle aged adults and predominantly in males, are the most frequently observed benign lung tumors that make up $4 \%$ of the total solitary pulmonary nodules ${ }^{1}$. Approximately $90 \%$ of pulmonary hamartomas are localized parenchymally and peripherally. Originating from the fibrous connective tissue of the bronchi, they consist of varying proportions of cartilaginous, osteoid, smooth muscle and adipose tissue; and the lesions are identified on the basis of the dominant tissue content such as the chondramatous, leiomyomatous, fibroleiomyomatous, lymphangiomatous or the adenofibromatous type ${ }^{2}$. Although they can arise in any part of the body, they are frequently observed in the lungs. Being mostly asymptomatic, they are often detected coincidentally by lung radiography ${ }^{3}$. We aimed in this study to discuss our clinical and surgical experience with lung hamartomas, a rare group of the solitary lung nodules.

\section{METHODS}

This study included 24 patients (14 males, 10 females) with a mean age of 50.6 years (23-66), who underwent surgical resection for pulmonary hamartomas between January 2005 and December 2017 in our hospital. All patients had two-directional lung radiography, and computerized thorax tomography. Malignancy was eliminated by histopathological examination of frozen sections. Patient records about their age, gender, clinical data, tumor localization, histopathological and radiological findings, and the applied surgical intervention were retrospectively reviewed.

\section{Surgical techniques}

All patients were operated under general anesthesia at the operating theatre. After placing patients on the operating table and inducing anesthesia, they were intubated using a double lumen tube. They were positioned on 
the operating table for a standard posterolateral thoracotomy incision, and they were scrubbed. Adjusted to the lateral decubitus position, the arm was suspended in abduction so that the scapula was maximally elevated. The table was tilted, and a $10 \mathrm{~cm}$ thick roll pillow was placed under the thoracic cage in order to maximally expose intercostal spaces. Using a single incision and $0^{\circ}$ telescope for imaging (Karl Storz, Hopkins II telescopes with a diameter of $5 \mathrm{~mm}$, a length of $29 \mathrm{~cm}$, and a trocar size of $6 \mathrm{~mm}$ ), wedge resections were performed using endo staplers. Entire pleura and pulmonary surfaces were examined following the operation. After performing a check for air leaks and hemostasis, a $28 \mathrm{~F}$ chest tube was placed through the incision site. All patients were extubated at the operating table and transferred to regular ward. Patients with pleural adhesions or tumor location not suitable for endoscopic resection were operated by thoracotomy opened through the 5 th intercostal space at the same position.

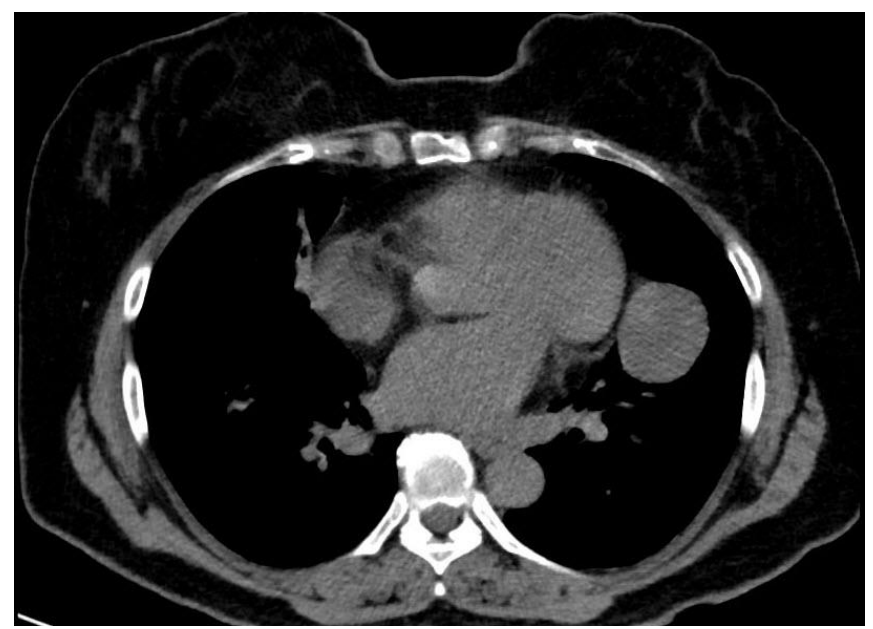

Figure 1: The CT thorax section of pulmonary hamartoma evaluated as a mass in the lung.

\section{RESULTS}

Of the 24 patients whose clinical data were evaluated, 17 (71\%) were asymptomatic while 7 had complaints of coughing, shortness of breath, and repetitive lung infections. On the basis of the radiological and clinical findings, 14
(58\%) were diagnosed with solitary pulmonary nodules; 7 (29\%) with a mass in the lung (Figure 1); and 3 (13\%) with a metastatic lesion. In $71 \%$ of the cases the diameter of the lesions was less than $3 \mathrm{~cm}$. The lesions were localized in the right lung in 16 cases and in the left lung in 8 cases. While 17 lesions were peripherally located, 7 lesions were centrally located. Three patients underwent transthoracic fine needle aspiration (FNA) biopsy procedure before the surgery. Decision for surgery was made after excluding any cytopathology. Surgical intervention consisted of videothoracoscopic wedge resection in $71 \%$ of the cases and thoracotomy wedge resection in $29 \%$. Hamartoma diagnoses were made after histopathological investigation of the excised tissue (Figure 2,3). Postoperative morbidity or mortality was not recorded.

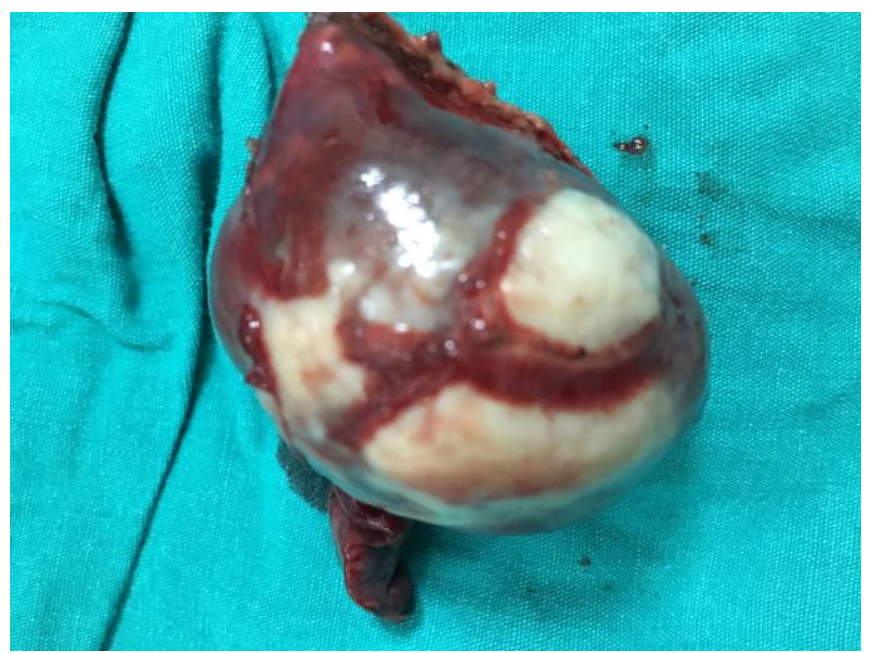

Figure 2: Appearance of the excised lung hamartoma.

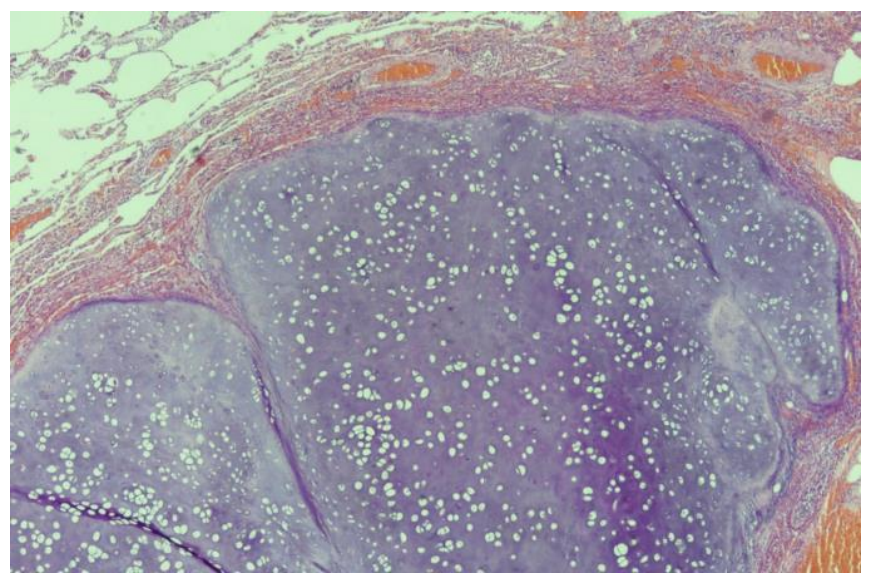

Figure 3: Microscopic appearance of the lung hamartoma. 


\section{DISCUSSION}

Pulmonary hamartomas are the most frequently diagnosed benign lung tumors that affect 2-4 times more commonly males than females. Most cases are observed in patients between 40 and 70 years of age 4 . In our series the male to female ratio was 1.4 , and the mean age of the patients was 50.6 years.

Connective, adipose and smooth muscle tissue embedded in a predominantly cartilaginous component can be seen in hamartomas 5 . Hamartomas often appear as solitary nodules and generally as single lesions in the periphery of the lung. Pulmonary hamartomas are categorized into two groups, namely the parenchymal and the endobronchial hamartomas ${ }^{6}$. In our series all lesions were of parenchymal origin, with $71 \%$ being peripherally localized. Endobronchial hamartomas were not observed in the small number of cases included in our study. Endobronchial hamartomas frequently cause coughing, hemoptysis and recurrent lung infections as compared to the peripherally localized and generally asymptomatic lesions, which are mostly detected coincidentally by lung radiography ${ }^{7}$. In most cases the diameter of a lesion is less than $3 \mathrm{~cm}$, although lesions as large as $25 \mathrm{~cm}$ and reaching $3.2 \mathrm{~kg}$ weight have been reported in the literature 5 . In our study 13 (54.2\%) excised lesions had dimensions less than $3 \mathrm{~cm}$.

Pulmonary hamartomas have specific radiological characteristics facilitating their discrimination from malignancies, one of which is their fat content (up to 50\%).Fat content in a lesion is a specific and reliable diagnostic marker for a hamartoma ${ }^{8}$. Another important feature of hamartomas is their calcification. Calcifications appearing as popcorn are characteristic for a hamartoma. However, such calcification can be observed in only $5-50 \%$ of all cases ${ }^{9-11}$. Although hamartomas display benign features due to these radiological characteristics, precise distinction between malignant and benign lesions can be made only after resection ${ }^{12}$.

At fludeoxyglucose positron emission tomography (PET-CT), most pulmonary hamartomas show no or very mild metabolic activity. In some cases, however, they can demonstrate active metabolism, which can raise the suspicion for malignancy, especially when dealing with lipid-poor pulmonary hamartomas ${ }^{13-15}$. PET-CT examination was not performed as part of radiological examination of our cases.

Hamartomas are tumors composed of mesenchymal tissues such as cartilage, fat, connective tissue and smooth muscle and can be found in virtually any organ system. These masses commonly develop sporadically but are also seen in certain syndromes such as Carney triad or tuberous sclerosis. Pulmonary hamartoma accompanied by gastric leiomyosarcoma and functional non-surrenal paraganglioma is termed as Carney triad ${ }^{16,17}$. Cowden syndrome, the multiple hamartoma syndrome, is characterized by mucocutaneous lesions, multiple benign internal organ tumors, and an increased tendency for breast, thyroid, urogenital, and gastrointestinal system cancers $^{18}$. Proteus syndrome include an asymmetric overgrowth of long bones, asymmetric macrocephaly, vertebral anomalies, hyperostosis, partial gigantism of hands or feet, cutaneous nevi, lipomas, and vascular malformations ${ }^{19}$. Pulmonary manifestations of tuberous sclerosis include lymphangioleiomyomatosis (LAM) that is characterized pathologically by a hamartomatous proliferation of smooth muscle-like cells in the lymphatics and small airways, leading to air trapping and extensive parenchymal replacement by cysts $^{20}$. No clinical sign associated with the above described multiple hamartoma syndromes was observed in our cases. 
Given the dense fibrocartilaginous consistency of pulmonary hamartomas, and difficulties during aspirating adequate material; and difficult interpretation of histopathological results makes diagnosis by means of FNA biopsy often inadequate. It has been shown that the incidence of correct diagnosis by FNA samples taken from hamartomas is lower than that with malignant lesions ${ }^{21}$. However, reports on the extent of diagnostic success after FNA is highly varied ${ }^{22}$. We performed FNA biopsy in three of our patients and after having eliminated any pathology, we decided proceeding with surgery. When non-surgical diagnostic tools are not possible, surgery becomes unavoidable. For patients diagnosed with a hamartoma preoperatively, surgery is not recommended until the lesion diameter increases over time. It is already known that the initial radiological appearance of 20\%-30\% of lung cancers resembles solitary pulmonary nodules. While considering these lesions benign, it should not be overlooked that they may coexist with other malignancies or may recur postoperatively. Therefore, postoperative follow-up of patients is imperative. In our series none of the cases presented with recurrence or lung cancer during a follow-up of 24 months.

In conclusion, pulmonary hamartomas mostly present as solitary nodules and appear as lesions with fat content and calcified foci. Definitive diagnosis as well as treatment of these lesions is possible only by surgical resection that is associated with a low level of morbidity and mortality risk ${ }^{23}$. During surgical intervention lung parenchyma should be protected as much as possible and the parenchyma outside the lesion location should be carefully investigated given the possibility of comorbidity of pulmonary hamartomas with malignancy. The patient should be put on postoperative follow up.
Declaration of Conflicting Interests: The authors declare that they have no conflict ofinterest.

Financial Disclosure: No financial support was received.

\section{REFERENCES}

1. Özlü T,Metintaş M,Kaya A. Solunum sistemi ve hastalıkları Temel başvuru kitabı.Cilt 2. (Respiratory system and its diseases - Reference book, Volume 2): Istanbul Medikal Yayıncılık 2010; 1511-12.

2. Okudela $K$, Umeda $S$, Otara $M$, et all. A case of pulmonary hamartoma with distinctive histopathological features: a discussion of its differential diagnosis and histogenesis. Pathol Int 2014; 64: 618-23.

3. Suut S, Al-Ani Z, Allen C, et all. Pictorial essay of radiological features of benign intrathoracic masses. Ann Thorac Med. 2015 Oct-Dec; 10: 231-42.

4. Ekinci GH, Haciömeroğlu 0 , Ersev A, et all. The frequency of lung cancer in patients with pulmonary hamartomas: An evaluation of clinical, radiological, and pathological features and follow-up data of 96 patients with pulmonary hamartomas. Rev Port Pneumol. 2017 Sep - Oct; 23: 280-6.

5. An J, Long $M$, Jiang $Y$, Jin Y. Concomitant a giant pulmonary bulla on the left lower lobe and hamartoma successfully treated by video-assisted thoracoscopic pulmonary wedge resection. AME Case Rep. 2017 Sep 26; $1: 2$.

6. Abdel Hady SM, Elbastawisy SE, Hassaballa AS, Elsayed $\mathrm{HH}$. Is surgical resection superior to bronchoscopic resection in patients with symptomatic endobronchial hamartoma? Interact Cardiovasc Thorac Surg. 2017 May 1; 24: 778-82.

7. Dimitrakakis G, Challoumas D, Rama Rao Podila S, et all. The challenge of pulmonary endobronchial chondromatous hamartomas.J BUON. 2014 Jan-Mar; 19: 60-5.

8. Elsayed H, Abdel Hady SM, Elbastawisy SE. Is resection necessary in biopsy-proven asymptomatic pulmonary hamartomas? Interact Cardiovasc Thorac Surg. 2015 Dec; 21: 773-6.

9. Siegelman SS, Khouri NF, Scott WW, et all. Pulmonary hamartoma: CT findings. Radiology 1986; 160: 313-7.

10. Oldham HN Jr, Young WG Jr, Sealy WC. Hamartoma of the lung. J Thorac Cardiovasc Surg 1967; 53: 735-42.

11. Ledor K, Fish B, Chaise L, Ledor S. CT diagnosis of pulmonary hamartomas. J Comput Assist Tomogr 1981; 5: 343-4. 
12. 9-Zehani-Kassar A, Ayadi-Kaddour A, Marghli A, et all. Clinical characteristics of resected bronchial hamartoma. Study of seven cases.Rev Mal Respir. 2011 May; 28: 647-53. 2011 Apr 16.

13. Asad S, Aquino SL, Piyavisetpat N, Fischman AJ. Falsepositive FDG positron emission tomography uptake in nonmalignant chest abnormalities. AJR Am J Roentgenol 2004; 182: 983-9.

14. Christensen JA, Nathan MA, Mullan BP, et all. Characterization of the solitary pulmonary nodule: 18F-FDG PET versus nodule-enhancement CT. AJR Am J Roentgenol2006; 187: 1361-7.

15. De Cicco C, Bellomi M, Bartolomei M, et all. Imaging of lung hamartomas by multidetector computed tomography and positron emission tomography. Ann Thorac Surg 2008; 86: 1769-72.

16. Settas N, Faucz FR, Stratakis CA. Succinate dehydrogenase (SDH) deficiency, Carney triad and the epigenome. Mol Cell Endocrinol. 2018 Jul 5; 469: 107 11.

17. Boikos SA, Xekouki P, Fumagalli E, et all. Carney triad can be (rarely) associated with germline succinate dehydrogenase defects. Eur J Hum Genet 2016; 24: 569-73.
18. Garofola C, Gross GP. Hamartoma, Cowden Disease (Multiple Hamartoma Syndrome). Stat Pearls Treasure Island (FL): Stat Pearls Publishing; 2018 - 2018 Oct 27.

19. Leiter Herrán F, Restrepo CS, Alvarez Gómez DI, et all. Hamartomas from head to toe: an imaging overview. $\mathrm{Br}$ J Radiol. 2017 Mar; 90 (1071): 20160607.

20. von Ranke FM, Zanetti G, e Silva JL, et all. Tuberous sclerosis complex: state-of-the-art review with a focus on pulmonary involvement. Lung 2015; 193: 619-27.

21. Xia Y, Wang KP. Transbronchial needle aspiration: where are we now? J Thorac Dis. 2013 Oct; 5: 678-82.

22. Klein JS. Transthoracic needle aspiration biopsy for the cytologic diagnosis of subsolid lung nodules. Cancer Cytopathol. 2016 Jul; 124: 451-2.

23. Serkan Bayram, Çağatay Tezel, Serdar Evman, ve ark. Sol ana bronş tümörüne sağ torakotomi ile izole sleeve rezeksiyon. Dicle Tip Dergisi/Dicle Medical Journal 2017; 44: 119-23. 